\title{
Å leve i en kropp som mangler leddsans
}

\author{
Jeg har en sjelden lidelse. Etter å ha gjennomgått Guillain-Barrés syndrom mistet jeg leddsansen uten at \\ musklene er blitt lammet. Man antar at ti mennesker på verdensbasis har samme tilstand.
}

Se kommentar side 192

1. august 1999 følte jeg at en influensa var på gang - igjen. Jeg hadde hatt tre omganger siden februar og tenkt at jeg burde spise litt sunnere eller trene litt. Jeg hadde nettopp flyttet fra Østlandet og startet i ny og mer krevende jobb i Nord-Norge, og antok at dette var årsak til at immunforsvaret ble mer belastet.

Men det føltes litt annerledes denne gangen. Det startet med at jeg følte prikking i hendene, lett mistet ting, hadde dårlig koordinasjon, ømhet og smerte i kroppen. Etter et par dager ble balansen også dårligere, og jeg oppsøkte legevakten. Legen fant ikke reflekser, og sendte meg videre til nevrologisk avdeling ved sykehuset. Nevrologen gjettet på Guillain-Barrés syndrom, ut fra måten jeg gikk på. Jeg ble innlagt samme kveld. Spinalvæskeprøve viste for høyt nivå av protein, og jeg fikk bekreftet diagnosen GuillainBarrés syndrom. Selv mener jeg dette er bivirkning av vaksiner jeg hadde tatt.

\section{De første to årene}

Da jeg våknet neste dag, var jeg lam i beina. I løpet av første dag visnet armene, og i de neste dagene ble jeg lammet fra nesen og ned, munnen inkludert. Det var vanskelig både å snakke og å spise. Jeg manglet smakssans, sult- og metthetsfølelse, hadde ingen temperaturfølelse, men svettet mye. Lungekapasiteten var på $17 \%$, hvilepuls opptil 145, og det ble igangsatt behandling med immunglobulin intravenøst. Dette stoppet utviklingen og jeg ble sakte men sikkert bedre.

De første månedene på sykehuset er litt uklare for meg. Jeg fikk mange medikamenter og hadde dårlig døgnrytme. Når jeg nå 12 år etter skriver dette, kan det være detaljer jeg ikke husker riktig.

Fra å være totalt lammet fra nesen og ned, kunne jeg etter et par uker bevege litt på hodet og etter hvert gjøre små bevegelser med fingre og tær. Etter et par måneder

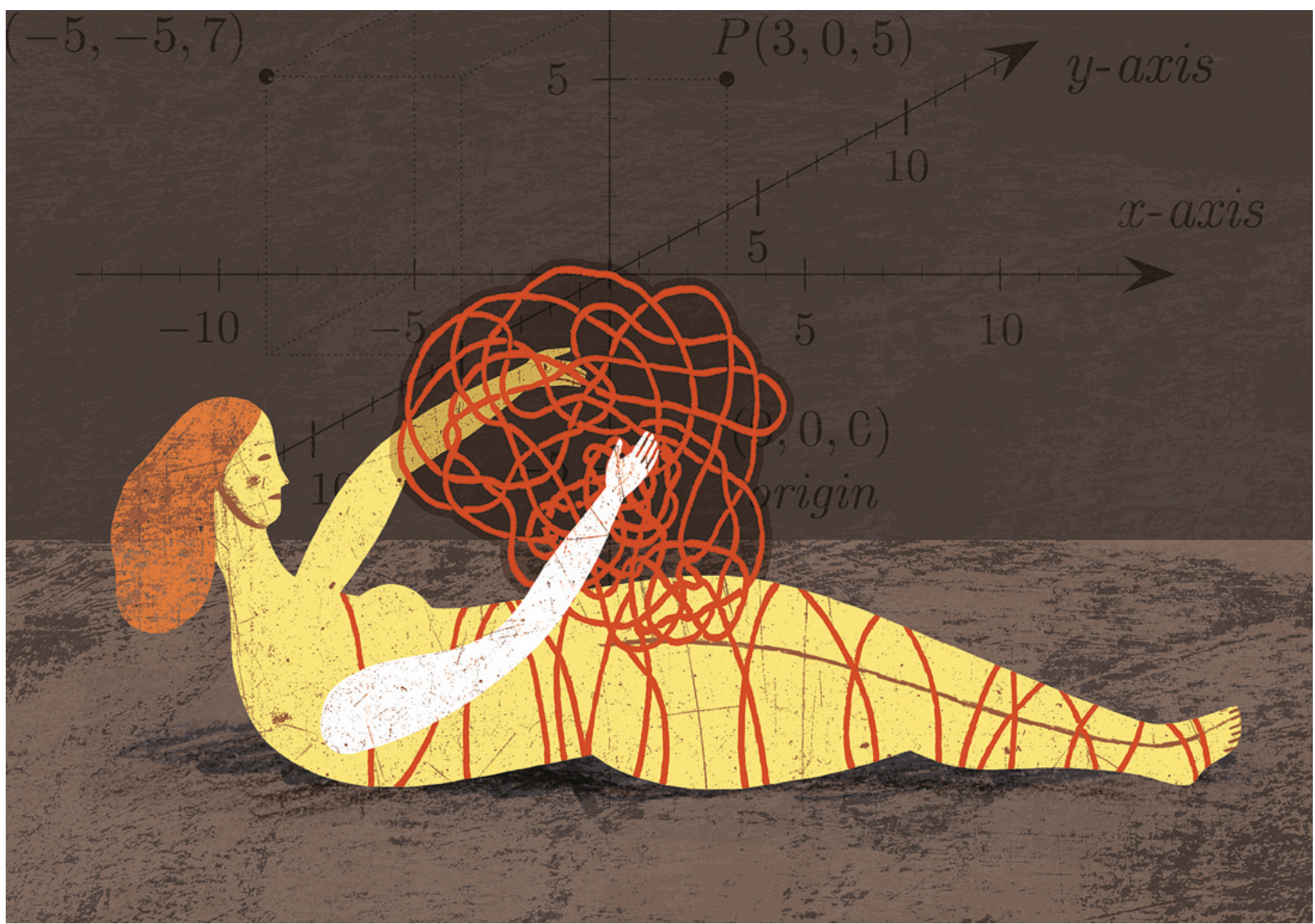


kunne jeg løfte og drikke av en flaske, holde en gaffel og føre mat til munnen, riktignok med mye søl. Etter omtrent fire måneder hadde jeg litt kontakt med magemusklene og kunne med hjelp sette meg opp i sengen med støtte og tilsyn. Etter 4-5 måneder kunne jeg med støtte fra to personer bli holdt oppreist i stående stilling, og etter ca. ett år stå noen sekunder uten støtte. Etter ca. to år nådde jeg det fysiske funksjonsnivået jeg har i dag, og etter det har teknikk og mestring blitt bedre. Jeg var på sykehuset til januar 2000, noen måneder på rehabilitering i Bodø og innlagt ved Sunnaas sykehus august 2000-februar 2001.

\section{Uten leddsans}

Det sensoriske mangler, jeg har ikke leddsans fra nesen og ned, så jeg føler ikke posisjon på leddene. Jeg mangler balanse og koordinasjon og er helt avhengig av synet for bevegelse. Signaler til musklene er normale, så jeg kan «snakke» til musklene, men det er øynene som bekrefter bevegelse og posisjon. Dette gjør bl.a. at jeg er helt avhengig av rullestol.

Hudfølelsen er også rammet, på en måte som gir en blanding av nummenhet og hypersensitiv følelse. Jeg kan føle noe berøring, spesielt bevegelse, og kjenner også forskjell på varmt eller kaldt, men ikke graden av det. Jeg kan heller ikke føle om noe er vått eller tørt, og kan ikke kjenne vannet mot huden når jeg bader eller dusjer.

\section{Eksempler på daglige gjøremål}

Jeg har alltid vært kreativ og drevet med håndverk, men å holde nål for å sy, er tilnærmet umulig. Det er vanskelig å holde alt verktøy som saks, kniv etc. Det samme gjelder penn for å skrive. Jeg har ikke leselig håndskrift og skriver derfor på PC. Jeg må holde øynene på tastaturet siden jeg ikke føler fingrene, verken når de treffer tastene eller hvor på tastaturet de er.

Det er vanskelig å holde kniv og gaffel samtidig, så jeg skjærer opp maten først, for så å spise med én hånd. Jeg pleier å spøke med at jeg er blitt som en mann: klarer ikke å gjøre to ting på en gang. Når jeg holder et glass, må jeg se på hånden hele tiden. Hvis jeg ser opp, velter ofte glasset fordi jeg ikke kjenner at hånden gir etter. Jeg kan ikke drikke av plastglass, fordi jeg knuser dem siden jeg ikke kjenner hvor hardt jeg holder.

Jeg må også passe på at jeg ikke biter meg $\mathrm{i}$ fingrene når jeg holder maten $\mathrm{i}$ hånden. Kjeks og brød knuser jeg også, fordi jeg holder for hardt. Løsningen er å legge det $\mathrm{i}$ hånden, $\mathrm{og}$ spise $\mathrm{av}$ åpen håndflate.

En annen utfordring er å ta hånden ned $i$ en veske for å plukke opp noe, det er ikke mulig. Tenk deg at du har på deg votter og gjør det samme. Jeg har hatt katter tidligere, og det var trist ikke å føle at jeg klappet dem, og vanskelig å løfte dem med riktig grep. Jeg har nedsatt styrke, og føler ikke tyngden på ting. Jeg løfter ikke mer enn en kilo med et grep, og bag med håndtak muligens $6-7 \mathrm{~kg}$.

Nok en utfordring møter jeg når det er mørkt. Når jeg legger meg, må jeg passe på at kroppen ligger riktig og legge dyna over meg før jeg slukker lyset. Jeg kan ikke ha det helt mørkt, for jeg føler ikke hvor armer og bein er. Jeg kan våkne av at det er kaldt, og vet da at dyna ikke er over meg. Da må jeg først finne hendene. Det gjør jeg ved å krafse med fingrene, da hører eller føler jeg hvor de er, og kan "snakke» til musklene for å få dem til å gripe dynen. Dette er kun mulig med litt lys slik at jeg kan se konturene av hendene. Klær krever også en viss tilpasning, for jeg klarer ikke å kneppe knapper. Jeg velger bukser med strikk i livet og overdeler med glidelås.

Jeg har tilpasset bil, men kjører kun på dagtid og når jeg er i god form, for jeg føler ikke hvor kroppen er. Jeg gir gass med foten, og kjenner jo på bilen at jeg treffer gassen, men kan ikke flytte beinet, så jeg må bremse med spesialtilpasset brems på hånden. På samme håndtak er det montert bryter, så jeg kan skru på blinklys med tommelen. Jeg føler ikke at jeg holder på rattet, så jeg holder den ene hånden festet $i$ et grep.
Jeg ser bevegelse i sidesynet, slik at jeg kan «snakke» til hånden og svinge riktig vei.

\section{Usynlig handikap selv med rullestol} Smerte og utmattelse er en del av tilværelsen. Jeg føler at dette gir større begrensning enn ikke å kunne gå. Rullestol kan man finne praktiske løsninger på, men når man er helt tom for energi og smerten brenner i kroppen, er det kun sengen som gjelder.

En annen utfordring er at ingen forstår meg. Det er en klisjé, men er riktig likevel. Det gjelder holdninger i samfunnet, men spesielt blant helsepersonell. Jeg ser jo helt frisk ut. Jo da, jeg sitter i rullestol, men jeg beveger både armer og bein. Jeg har ofte fått høre at jeg ser for frisk ut. Månedene på Sunnaas var veldig traumatiske, der møtte jeg mye manglende forståelse. Jeg fikk høre at grunnen til at jeg ikke kunne gå, var at jeg ikke trente nok og satt og syntes synd på meg selv. De som kjenner meg, kan fortelle en helt annen versjon. De mener at det ikke er mangel på selvinnsikt når jeg omtaler meg selv som en positiv ståpåperson. For et par år siden var det en lege som lurte på om dette kanskje var psykisk. Fint, svarte jeg, da kan du jo bare henvise meg til en terapeut.

Jeg har møtt mye vrangvilje i kommunen der jeg har bodd siden jeg ble skrevet ut fra Sunnaas. Jeg bodde først i bolig på sykehjem, men jeg orket ikke miljøet og flyttet til en privat leilighet som ikke kunne tilrettelegges, og bodde innesperret der i om lag halvannet år før kommunen tilbød meg en tilrettelagt bolig. Begrunnelser som at jeg skulle bli frisk, ikke var handikappet nok eller ikke hadde stort nok hjelpebehov, ble brukt som argumenter for å gi meg avslag på søknader. Det tok fire år fra jeg ble syk til det mest elementære var på plass: en funksjonell bolig, bil og assistent.

\section{Wenche Lise Ingier}

e-post@wenche-lise.no

Mottatt 30.11. 2010 og godkjent 22.12. 2011 Medisinsk redaktør Erlend Hem. 